\title{
Teaching methods in primary education from the teacher's point of view
}

\author{
Martin Skutil ${ }^{1 a}$, Klára Havlíčková ${ }^{1}$, and Renata Matějíčková ${ }^{1}$ \\ ${ }^{1}$ Institute of Primary and Preprimary Education, Faculty of Education, University of Hradec Králové, \\ Rokitanského 62, 50003 Hradec Králové, Czech Republic
}

\begin{abstract}
The paper is based on the current research project aimed at finding the use of teaching methods in primary education. The aim of this paper is to analyse and describe the current situation based on the results of the quantitative survey. The primary outcome introduced in this paper is to describe the current situation in the Czech Republic from the teacher's point of view and to analyse strengths and weaknesses of different teaching methods in educational practice. The fundamental research method was participant observation. The paper represents the first part of a wider research which is focused on all participants (teachers, pupils, parents) of the educational process.
\end{abstract}

Keywords: Teaching methods; primary education; teacher's profession, teaching methodology

\section{Insight into the issue}

Changes in the view of the overall concept of education are reflected in the approach to teaching. In recent decades, there is a shift from the traditional approach [23], which is characterised by the transmission of finished information, to a constructivist approach. According to Papert [14], traditional teaching methods are the methods when students perform certain instructions, work according to the model. Due to the development of science and ICT, since the end of the 20th century there has been a replacement of direct teaching methods with principle of knowledge constructing in specific increments. The purpose of education is not and cannot be the transmission of the truth only, as it is in the case of the so-called transmissive pedagogy (its method is memorising, transmission of non-problematic "facts" - knowledge into the consciousness of a pupil). A more substantial challenge facing education is to equip pupils with the ability to navigate in the vast sea of knowledge and learn to use them correctly.

\footnotetext{
a Corresponding author: martin.skutil@uhk.cz
} 
Constructivist pedagogy focuses on the way of how knowledge and understanding arise, on the process of how we use the ambiguous reality, how we construct instrumental truths find useful solutions. At any time a person has a complete form of the world, i.e. finished structure, in their consciousness. New facts either fit in the structure or they are in conflict with this structure and cause its change. The aim of a teacher is to enable a student to examine these images (preconceptions), facilitate the integration of new information into existing mental structures and assist in reflection of not only new knowledge but also in the way it was achieved and how it was involved in the image of the world, [18].

Another feature of the constructivist education reform is the change in the status of a teacher, from the information provider to a facilitator and guide in acquiring them. Even teachers can sometime learn from their pupils. Great emphasis is placed on the inter-subject relationships and preparation for teamwork. As it can be seen, these requirements exactly coincide with the needs of sociologists-defined imminent information society as well as with the results of a wide range of disciplines.

A constructivist teacher is seen as a guarantor of the method, as an assistant, study guide and ensures that every pupil can achieve the highest possible level of development. A pupil comes to school with certain knowledge and, therefore, to think about what they know and to develop their knowledge.

\section{Theoretical background}

Modern pedagogy supports and promotes a teaching methodology that is both diversified and flexible, providing a very wide range of teaching-learning methods. The large number and the great diversity of teaching methods used in modern pedagogy provide opportunities for the enrichment and development of the teachers' teaching and educational expertise. A teaching method is an effective way of organising and guiding learning, a common way of procedure that unites a teacher's and a students' efforts. A teacher's creativeness and personal development level determine how these teaching methods are used and combined, $[15,21]$.

Cognitive theories suggest that learning occurs with the result of information formation developing with dominant priorities. According to this, learning is based on that a learner processes the information that he configured with his own cognitive process and this process shapes new learning. The advances in this direction are related to what they learn and how they learn, not how much they learn. The main metaphor expected to be argued is, perhaps, students are active learners rather than they are passive receivers, [11].

The Teaching and Learning International Survey [13] noted that "in the classroom, teachers in all countries put greater emphasis on ensuring that learning is well structured than on student-oriented activities which give them more autonomy. Both of these teaching practices are emphasised over enhanced learning activities such as project work. This pattern is true in every country".

In the recent local and international methodological literature the teaching methods and practices have been given special attention, but when it comes to their understanding, defining and naming, a complete agreement has not been achieved yet. First of all, there are different terms in literature that make it difficult to communicate, so within teaching methods, authors also discuss the terms such as methods in the class, methods of teaching and learning, organizational types of the teaching and learning processes, [1].

According to Maňák and Švec [9], a teaching method represents "a dynamic element" in teaching, which compared with the content and organizational forms changes relatively rapidly and adapts to new circumstances and objectives. The teaching methods, however, are not the decisive determinant of teaching, but only one of the elements of the educational system, and therefore cannot replace the missing content and compensate the indistinct 
target. On the contrary, they are tied to the overall concept of teaching and only within it are they fully functional and effective. Also Mojžíšek [12] talks about teaching methods in the same way, according to who a teaching method is a teaching specifically didactic activity of the subject and object of teaching, developing the educational profile of a student, while acting educationally, in terms of training and educational objectives and in accordance with teaching and educational principles. It lies in the modification of content, directing the activity of subject and object, organization of the sources of knowledge, techniques and procedures, ensuring fixation or control of knowledge and skills, cognitive attitudes, interests and processes.

On the contrary, they are tied to the overall concept of teaching and only within it are they fully functional and effective. Many other authors, e.g. Harmer [5, 20 and 16] talk about teaching methods in the same way, according to whom a teaching method is a teaching specifically didactic activity of the subject and object of teaching, developing the educational profile of a student, while acting educationally, in terms of training and educational objectives and in accordance with teaching and educational principles. It lies in the modification of content, directing the activity of subject and object, organization of the sources of knowledge, techniques and procedures, ensuring fixation or control of knowledge and skills, cognitive attitudes, interests and processes.

Teaching methods are among the basic educational categories. They can be defined as a structured system of teaching activities of a teacher and learning activities of a pupil, which aims to achieve educational goals. The term Teaching method refers to the general principles, pedagogy and management strategies used for classroom instruction. Your choice of teaching method depends on what fits you - your educational philosophy, classroom demographic, subject area(s) and school mission statement, [4, 19].

Liu \& Shi [8] characterized teaching method by a set of principles, procedures or strategies to be implemented by teachers to achieve desired learning in students. Mayer [10] says, that as constructivism has become the dominant view of how students learn, it may seem obvious to equate active learning with active methods if instruction. This means the role of the teacher becomes one of facilitator and supporter, rather the instructor. On the other hand, Kirschner at al. [7] pointed out that as a consequence of overload, learners can engage in problem solving activities for external periods and learn almost nothing.

According to Westwood [23], now, the appropriateness and efficacy of a particular teaching method can be considered in relation to the type of learning it is supposed to bring about, and in relation to the characteristics of learners.

\section{Research methodology}

The performed research is designed as a qualitative and quantitative survey. We opted for this combination mainly because the aim is not only to describe the methods of the work, but also to understand why teachers approach teaching in the selected way. We proceed from the design of Miles and Huberman presented by Flick [10]. Standard methodological procedures were used for data processing, $[3,17]$.

\subsection{Research tool}

For the quantitative part based on observation, a standardized evaluation tool targeted at teaching methods and forms was selected, it was prepared by [24]. This research tool has the character of a criteria record, which is based on the categorization of teaching methods and forms. It defines eight teaching methods (with the additional category of "other methods") and three organizational forms of teaching (with the additional category of "other 
forms"). The tool has three basic parts - The characteristics of individual teaching methods and forms; inspection arch; discussion part. Therefore, covering the entire spectrum of quantitative to qualitative approach. The inspection arch contains a table for basic information concerning teaching, a range with two defined degrees and a table outlining the specific methods and forms of teaching. There is also the option of having other methods and forms than those that are listed, if they occurred. Discussion should lead to a structured reflection of teaching in terms of forms and methods, and to outline ways of how to work with the methods and forms of teaching in the future.

\subsection{Research sample}

The research sample consisted of 42 teachers working in primary schools, particularly in the 4th and 5th grade, they teach the courses of Geography, History and Biology. Selection of the research sample was limited geographically to the regions of Hradec Králové, Liberec, Pardubice and Ústí nad Labem, i.e. northeast Bohemia. In this area random stratified sampling was used, where the aim was to obtain teachers from both large, fully organized schools as well as small schools.

\section{Selected research results}

In this paper we present the selected results from a broader research survey. Our goal is at least to generally show how teachers work with teaching methods and how they perceive their application in the educational process in terms of didactics.

Table 1. Occurrence of teaching methods in education.

\begin{tabular}{lll}
\hline & Frequency & Frequency in \% \\
\hline Narration & 12 & 28.5 \\
Interpretation & 32 & 76.2 \\
Working with text & 30 & 71.4 \\
Interview & 32 & 76.2 \\
Graphically demonstrative & 30 & 71.4 \\
Skill-practical & 24 & 57.1 \\
Activating & 20 & 47.6 \\
Comprehensive & 18 & 42.6 \\
other & 4 & 9.5
\end{tabular}

The results show that the most frequent methods include interpretation and conversation. These are closely followed by the methods of working with text and graphically demonstrative methods. Those results can be seen positively from our point of view.

Teachers try to pass the greatest amount of information to pupils and at the same time discuss it in order to understand. This corresponds to the idea of constructivist thinking, whereby the aim is to pass information to pupils as well as make sure that they understand it and know how to apply it in everyday life. The principle of clarity in the form of skillpractical methods is also applied. With regard to the necessary support of literacy and the incorporation of students into information society [6], we consider a high level of representation of work with text as important as it can develop both essential aspects of life for primary school pupils. 
Table 2. Preferred methods of teaching from the perspective of teachers.

\begin{tabular}{lcc} 
& Frequency & Frequency in \% \\
\hline Narration & 6 & 10.7 \\
Interpretation & 4 & 7.1 \\
Working with text & 4 & 7.1 \\
Graphically demonstrative & 10 & 17.9 \\
Skill-practical & 6 & 10.7 \\
Activating & 4 & 7.1 \\
Comprehensive & 6 & 10.7 \\
Didactic game & 2 & 3.6 \\
Individual lessons & 2 & 3.6 \\
Group lessons & 10 & 17.9 \\
Collective lessons & 2 & 3.6 \\
\hline
\end{tabular}

In connection with the observed phenomena, in the subsequent interview with teachers we wondered which teaching methods they prefer. It is interesting that the most popular methods are those that require larger pupil activity - i.e. the graphically demonstrative methods, and consequently, methods which are associated with pupils group work. This fully corresponds to constructivist thinking of teachers, which is common in the Czech environment. On the other hand, there is a question why teachers do not use these elements in practice to a greater extent?

The results obtained show that the thinking of teachers is set in the right way, with regard to today's paradigm of education. This is also confirmed by other preferred methods in the order - i.e. skill-practical and comprehensive methods.

Table 3. Educational goals developed by appropriate methods from the teachers' point of view

\begin{tabular}{lcc}
\hline$\cdot$ & Frequency & Frequency in \% \\
\hline Pupil searches & 4 & 7.1 \\
Pupil knows & 14 & 25.0 \\
Pupil names & 6 & 10.8 \\
Deepening knowledge & 4 & 7.1 \\
Development of independence & 4 & 7.1 \\
Social interaction & 10 & 17.9 \\
Repetition & 14 & 25.0 \\
\hline
\end{tabular}

From general didactic point of view, we also wondered whether the methods used correspond with the elements of cognitive skills that teachers most often develop or would like to develop in pupils. In this case, we are somewhat surprised because previous constructivist approaches would suggest that teachers are more focused on knowing how to find information, develop independence and deepen knowledge.

It appears, however, that the objectives are more traditional, i.e. the interest of teachers is for a pupil to know the curriculum (beware, it does not mean to also understand it), to name and repeat the curriculum. Here we see a significant disproportion, and also a challenge for further research. 


\section{Summary}

The results of our survey show that teachers prefer teaching methods in-between the transmissive and constructivist approach to education. The most commonly used methods include interpretation, which is a typical representative of the transmissive approach. We believe that the reason for this is pressure from the education system, which is built as a system of component testing, usually targeted at pupils' knowledge. Pressure from society to be successful is so strong that teachers cannot dispense of this type of education in their work.

This thesis is supported by the finding that teachers themselves prefer methods that are more based on the activity of pupils and therefore they belong more in the framework of constructivist approach. It shows a shift in the mind-set of teachers, who believe that for the future life of pupils it is important to have knowledge as well as the ability of critical thinking and independent, constructive work.

In contrast, however, there are results which point to a miss-match between the intent of teachers and real teaching activities. If teachers themselves prefer the constructivist approach, with regard to educational goals, the goals are set by them so that knowledge and repetition are again in the highest position of importance. This corresponds with the results of the observation (see Tab1).

From our perspective, it is possible to draw a number of conclusions:

- Teachers are internally persuaded of the benefits and necessity of the constructivist education system at primary school. It manifests by their internal preferences of the teaching methods.

- Pressure from the system and thereby education providers and parents is so strong that knowledge outweighs the application of the learnings. Schools choose methods that to a larger extent support memorisation.

- In terms of didactics, there are more education goals chosen supporting memory learning, at the expense of active learning. This does not correspond with the proclamations of the educational policy [2], but it shows the real state of education.

Conclusions presented are the output of sub-examination, it is not a final evaluation of the discussed state. They will be further developed, analysed, discussed and presented.

\section{Acknowledgements}

This paper was written as part of a specific research project at the Faculty of Education, University of Hradec Králové No. 2104/2015 Teaching Methods in Primary Education from Participants of Educational Process Point of View.

\section{References}

1. Braičić, Z., Đuranović, M. \& Klasnić, I., Teaching and Learning Methods and Practices in Science and Social Studies Lessons. Croatian Journal of Education 17, Sp.Ed.No.1 83-95, (2015).

2. FEP EE - Framework Education, Programme for Elementary Education, Retrieved from www.vuppraha.cz/wp-content/uploads/2009/12/RVP_ZV_EN_final.pdf, (2007).

3. Gorard, S., Quantitative Methods in Educational Research. London: Continuum, (2001).

4. Gotz, T., Lohrmann, K., Ganser, B., \& Haag, L., Einsatz von Unterrichtsmethoden Konstanz oder Wandel? Empirische Padagogik, 19, 4, 342-360, (2005). 
5. Harmer, J., How to teach English. England: Addison Wesley Longman Limited,(1998).

6. Havigerová, J.M., Pupils' Information Behaviour - Introduction, Survey and Theoretical Background. In: I. Nowosad and G. Miłkowska, (2011).

7. (Eds.), A Child in School Setting. Toruń: Adam Maszalek. Kirschner, P. A., Sweller, J., \& Clark, R. E., Why minimal guidance during instruction does not work: An analysis of the failure of constructivist, discovery, problem-based, experiential, and inquiry-based teaching. Educational Psychologist, 41, 75-86, (2006).

8. Liu, W. \& Shi, J., An Analysis of Language Teaching Approaches and MethodsEffectiveness and Weakness. US-China Education Review, 4, 1, 69-71, (2007).

9. Maňák, J. \& Švec, V. Výukové metody [Teaching methods]. Brno: Paido, (2003).

10. Mayer, R. E., Should There Be a Three-Strikes Rule Against Pure Discovery Learning? American Psychologist, 59, 1, 14-19, (2004).

11. Mayer, R. E., Cognition and instruction: Their historic meeting within educational psychology. Journal of Educational Psychology, 84, 4, 405-412, (1992).

12. Mojžíšek, L., Vyučovací metody [Teaching methods]. Praha: SPN, (1988).

13. OECD, Creating Effective Teaching and Learning Environments. First Results from TALIS (Teaching and Learning International Survey). Retrieved from http://www.oecd.org/dataoecd/16/14/44978960.pdf, (2009).

14. Papert, S., Perevorod v poznanii: deti, kompjutery i plodotvornyje ideji. Moskva: Pedagogika, (1989).

15. Samfira, M. \& Fărăgău-Dragoș, M., Pre-service students' assessment of teaching methods in different subject areas. Research Journal of Agricultural Science, 46, 2, (2014).

16. Scrivener, J., Learning Teaching. Oxford: Macmillan, (2005).

17. Silverman, D., Interpreting qualitative data: methods for analyzing talk, text, and interaction. London: SAGE, (2006).

18. Skutil, M., Havlíčková, K. \& Matějíčková, R., Educational process in terms of teaching methods and organisational forms in small schools. New horizons in education - INTE 2014 conference proceedings. Sakarya: Sakarya Üniversitesi, 359-363, (2014).

19. Skutil, M., View of primary education in terms of the application of teaching methods in the educational process focusing on project based teaching. International conference of education, research and innovation (ICERI 2014). Valencia: IATED, 6437-6443, (2014).

20. Storch, D., Deutsch als Fremdsprache-Eine Didaktik. München: Wilhelm Fink Verlag, (1999).

21. Teaching Methods, Teach Make a Difference [online]. Retrieved September 9, 2014 from http://teach.com/what/teachers-teach/teaching-methods, (2014).

22. Tonnuci, F., Vyučovat nebo naučit? [Teach or to teach?]. Praha: Pedagogická fakulta UK, (1991).

23. Westwood, P.S., What Teachers Need to Know about Teaching Methods? Camberwell, Vic.: ACER Press, (2008).

24. Žák, V.,Metody a formy výuky: hospitační arch [Teaching methods and Organizational forms of education: observation sheet of paper]. Praha: Národní ústav pro vzdělávání, (2012). 